Australian Journal of

Crop Science

AJCS

AJCS 13(12):1927-1935 (2019)

ISSN:1835-2707

doi: 10.21475/ajcs.19.13.12.p1384

\title{
Influence of water stress on phenological development, biomass production and yield of Malaysian aerobic and lowland rice
}

\author{
Nadzariah Kamarul Zaman ${ }^{1 *}$, Mohd Yusoff Abdullah" ${ }^{1 *}$, Sariam Othman², Nadzirah Kamarul Zaman ${ }^{1}$ \\ ${ }^{1}$ Ecophysiology Res. Group, Fac. Of Plantation and Agrotechnology, Universiti Teknologi MARA (UiTM), P.O. Box 40450, \\ Shah Alam Selangor, Malaysia \\ ${ }^{2}$ Malaysian Agriculture and Research Development Institute (MARDI), 43400 Serdang Selangor, Malaysia
}

*Corresponding authors: nadzariahkz@yahoo.com; myusoffa@gmail.com

\begin{abstract}
This experiment was conducted to examine the comparative growth performance and yield of the first Malaysian aerobic rice variety, MARDI Aerob 1 (MA1) along with local lowland rice, MR 253 grown under water stress condition at selected growth stages. The experiment consisted of four treatments with three replications arranged in a randomized complete block design. The four treatments consisted of the control with no water stress throughout $\left(T_{1}\right)$, and water stress imposition at panicle initiation $\left(T_{2}\right)$, flowering $\left(T_{3}\right)$ and ripening $\left(T_{4}\right)$ stages. Water stress treatments were terminated when water deficit symptoms such as leaf rolling and wilting were detected. The effects of stress were assessed using parameters related to phenology, biomass and yield components. Results showed that both varieties were significantly affected, when water stress was imposed at the panicle initiation stage. At this stage, the water stress delayed the phenological development, reduced the panicle dry mass, and severely caused grain yield reduction for both varieties. The MR 253 variety had higher grain yield than MA1 under normal aerobic condition but not under water stress, while MA1 still was able to maintain reasonable high yield even under water stress condition, except when the water stress occurred at the panicle initiation stage. Panicle initiation stage was the most sensitive period for both varieties as water stress at this stage greatly affected the overall growth performance and grain yield for both varieties.
\end{abstract}

Keywords: Aerobic rice; biomass; MARDI Aerob 1; MR 253; phenology; water stress; yield.

Abbreviations: GLAl_Green leaf area index; $\mathrm{K}_{2} \mathrm{O} \_$Potash; LAI_Leaf area index; LDM_Leaf dry mass; MA1_MARDI Aerob 1; MARDI_Malaysian Agricultural Research and Development Institute; N_Nitrogen; $\mathrm{P}_{2} \mathrm{O}_{5}$ P Phosphate; Par._Parameter; PDM_Panicle dry mass; PI_Panicle initiation; RDM_Root dry mass; SDM_Stem dry mass; TDM_Total dry mass; Var._Variety.

Introduction

Water plays an important role in rice production system especially in Asia, which is highly dependent on irrigated rice cultivation system (Shashidhar, 2007). Unlike other cereals, rice has special adaptability that can tolerate water-submerged condition (Lu and Chang, 1980). A new development such as aerobic system has demonstrated that rice can be grown not only under submerged water, but also under dry soil condition (Lal et al., 2013). This wide adaptation has been related to mechanisms or responses that enable plant to withstand the stress environments (Steponkus et al., 1980).

Limited water availability in the future coupled with climate change effects may reduce the capacity of farmers to irrigate their fields, which may result in an increase in incidence to crop water stress (Chauhan and Abugho, 2013). Drought generally delays the rice phenological development and the effects vary with genotypes (Haque et al., 2006), as well as timing and severity of drought (Fukai and Kamoshita, 2005).
Rice with short growth cycle usually use less water, but yield could also be low due to a shorter cumulative duration for daily photosynthesis (Vadez et al., 2011; Richards, 2000). On the other hand, longer growth cycle enables more photosynthesis that promotes high yield, but the crops would likely be more susceptible to the predicted drought and diseases that may take place in the later part of the growth period (Acquaah, 2009).

Drought stress can cause imparity on dry matter partitioning, assimilates translocation and phloem loading, as well as limiting the sizes of source and sink tissues (Farooq et al., 2009). Generally, under water stress the new growth in leaves and shoots would be limited to minimize water loss and at the same time expand their root systems to maximize the absorption of soil water (Shahzad et al., 2016). The assimilate partitioning between shoot and root would not be severely affected when the plants were gradually exposed to drought 
stress, unless the plants already experienced severe stress (Asch et al, 2005). There was no distinction in the production of below and above ground biomass of rice grown under aerobic system when then soil conditions is maintained approximately at field capacity, whether plants were grown under flooded or aerobic conditions (Mitchell et al., 2012).

Information on the adaptation of the new local aerobic rice variety MARDI Aerob 1 to the limited water under field condition is still lacking. This study was aimed to examine the comparative growth performance and yield of the first Malaysian aerobic rice variety with existing local lowland rice grown under water stress condition given at selected growth stages. The understanding of the varietal responsiveness to water stress at different growth stages are crucial for continuous development and improvement of aerobic rice system in local area.

\section{Results}

\section{Phenological development as affected by water stress}

In general, MA1 variety had shorter growing period in the range of 86 to 95 DAS, as compared to MR 253 with the range between 104 to 121 DAS (Table 3). On the average, the water stress at the panicle initiation stage delayed the appearance of the $1^{\text {st }}$ and $100 \%$ ripening of MA1 significantly, with delays of 12 and 8 days, respectively, compared with the control. For MR 253, water stress at the same stage delayed the completion of $50 \%$ and $100 \%$ ripening by 11 and 15 days, respectively, as compared to control.

In contrast, water stress at the flowering stage hasten the start of ripening process of MA1 but not MR 253. The MA1 attained $100 \%$ ripening at 75 DAS that was 12 days earlier than the control.

Water stress at the ripening stage did not significantly affect the ripening progress of both varieties, compared with control. The MA1 and MR 253 reached 100\% ripening at 86 and 104 DAS, respectively, with differences of 1 and 2 days earlier than the control.

\section{Biomass production as affected by water stress}

Water stress imposed at all stages significantly reduced the SDM but not the LDM, LAI, GLAI and RDM of MA1, whereas the PDM and total biomass of MA1 were reduced significantly, when water stress was imposed at the panicle initiation stage (Fig. 2). However, for MR 253, water stress at all selected growth stages did not affect the LDM, SDM, RDM, and total dry mass. However, the PDM of MR 253 was reduced significantly, when water stress was imposed at the panicle initiation stage. The highest LDM, LAI, GLAI, SDM, RDM, PDM and total dry mass recorded value were $263.55,4.72,3.86,671.69,673.85$, 465.39 and 2048.71 for MA1, respectively, and 418.77, 8.21, 7.54, 917.05, 1540.53, 410.92 and 3266.27 for MR 253, respectively, regardless of treatments. In general, MR 253 exhibited higher LDM, LAI, GLAI, SDM, RDM and total dry mass, but lower PDM, when compared to that of MA1.

\section{Effects of leaf and soil moisture status on biomass production parameters of MA1 and MR 253}

The correlation studies of rice variety MA1 and MR 253 are shown in Table 4. There was a significant positive correlation between leaf relative water content with soil moisture content $\left(r=0.93^{* * *}\right)$ in MAI. The leaf RWC and SMC were both correlated positively with total dry mass $\left(r=0.53^{* *}, r=0.56^{* *}\right.$ respectively) but not with leaf area index ( $r=0.27 n s, r=0.33 n s$ respectively) and green leaf area index ( $r=0.35 n s, r=0.40 n s$ respectively).

Similarly with MAl, there was a significant positive correlation between relative water content and soil moisture content $\left(r=0.73^{* * *}\right)$ in MR253. Both of these parameters were positively correlated with total dry mass $\left(r=0.43^{*}, r=0.44^{*}\right.$ respectively) but not significantly with leaf area index $(r=0.06 n s, r=0.21 n s)$ and green leaf area index ( $r=0.08 n s$, $r=0.18 n s$, respectively).

\section{Yield components as affected by water stress}

Water stress at the panicle initiation stage resulted in significant reduction of filled grain, while water stress at the flowering stage resulted in significant higher percentage of filled grain of MA1 (Table 5). On the other hand, water stress at both panicle initiation and flowering stages resulted in significant reduction in percentage of filled grain of MR 253. The highest percentage of filled grain recorded by MA1 and MR 253 were $77.3 \%$ (under water stress at the flowering stage) and $63.5 \%$ (under water stress at the ripening stage), respectively.

Conversely, water stress at the panicle initiation stage resulted in significant higher percentage of empty grain, while water stress at the flowering stage resulted in significant reduction in percentage of empty grain of MA1. On the other hand, water stress at the panicle initiation and flowering stages resulted in significant higher percentage of empty grain of MR 253. The highest percentage of empty grain recorded by MA1 and MR 253 were $99.9 \%$ and $98.3 \%$, respectively (under control).

Water stress at the panicle initiation also resulted in significant reduction of grain yield of MA1. Unlike MA1, the grain yield of MR 253 significantly reduced when water stresses were imposed at all selected growth stages. Both MA1 and MR 253 recorded highest grain yield under control treatment, with $22.9 \mathrm{~kg} / \mathrm{ha}$ and $26.7 \mathrm{~kg} / \mathrm{ha}$, respectively.

\section{Discussion}

The present study (Table 3 ) showed that water stress at the panicle initiation stage delayed the full maturation $(100 \%)$ of both MA1 and MR 253. On the other hand, water stress at the flowering stage hasten the full maturation $(100 \%)$ of MA1 but not MR 253. The water stress at the ripening stage, however, did not significantly accelerate the ripening progress in both varieties, as MA1 and MR 253 fully ripened one and two days earlier than the control. It was suggested that panicle initiation was the most sensitive stage to water stress, as it was severely delayed the maturation of both varieties, especially MR 253. The finding of this study was in agreement 
Table 1. The water stress period based on crop age (DAS) and water stress duration (Days) at various growth stages given for both MARDI Aerob 1 (MA1) and MR 253.

\begin{tabular}{lll|lc}
\hline Growth Stage & \multicolumn{2}{c|}{$\begin{array}{c}\text { Imposition of water stress period } \\
\text { (DAS) }\end{array}$} & $\begin{array}{c}\text { Stress period duration } \\
\text { (days) }\end{array}$ \\
\cline { 2 - 5 } & MA1 & MR 253 & MA1 & MR 253 \\
\hline Panicle initiation & $44-53$ & $56-71$ & 10 & 16 \\
Flowering & $56-71$ & $77-92$ & 16 & 16 \\
Ripening & $77-88$ & $95-105$ & 12 & 11 \\
\hline
\end{tabular}

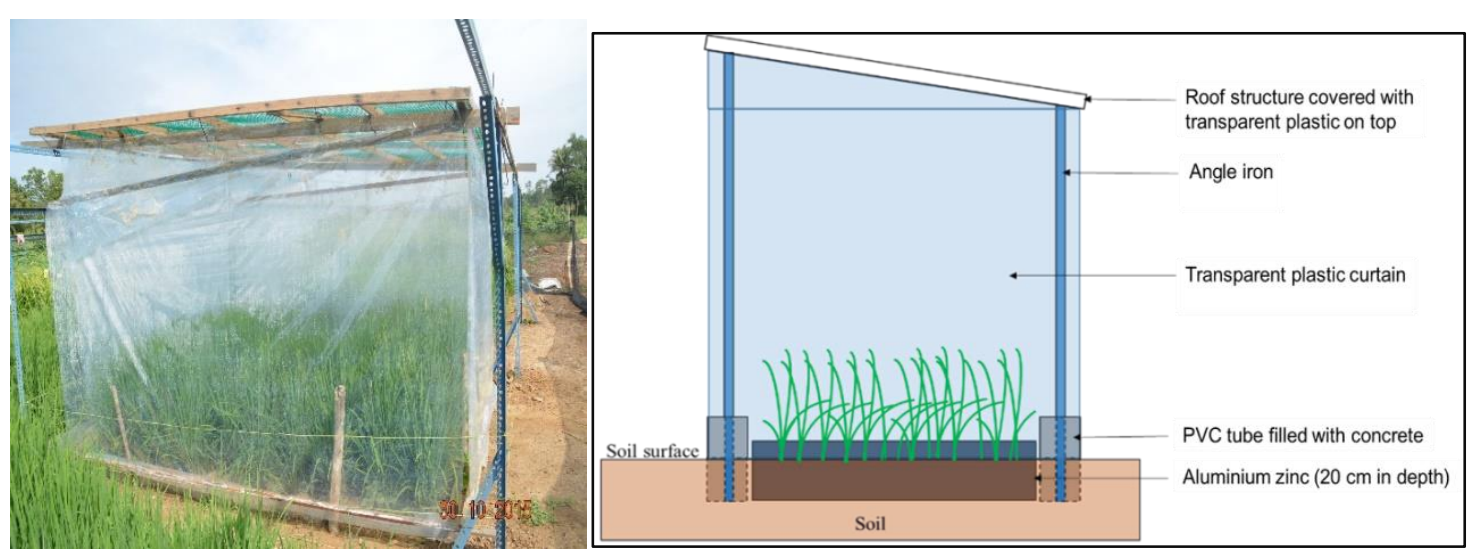

Fig 1. View and details of a metal structure setup for water stress plots

Table 2. Final harvest based on maturation period (DAS) of MARDI Aerob 1 (MA1) and MR 253 under various water stress treatments.

\begin{tabular}{llll}
\hline Treatment & Replication & \multicolumn{2}{c}{ Final harvest (DAS) } \\
\cline { 3 - 4 } & & MA1 & MR 253 \\
\hline T1 & 1 & 84 & 105 \\
& 2 & 88 & 112 \\
& 3 & 95 & 102 \\
\hline T2 & 1 & 95 & 121 \\
& 2 & 95 & 121 \\
& 3 & 75 & 121 \\
\hline T3 & 1 & 75 & 108 \\
& 2 & 75 & 105 \\
& 3 & 88 & 108 \\
\hline T4 & 1 & 84 & 105 \\
& 2 & 87 & 103 \\
& 3 & & 105 \\
\hline
\end{tabular}



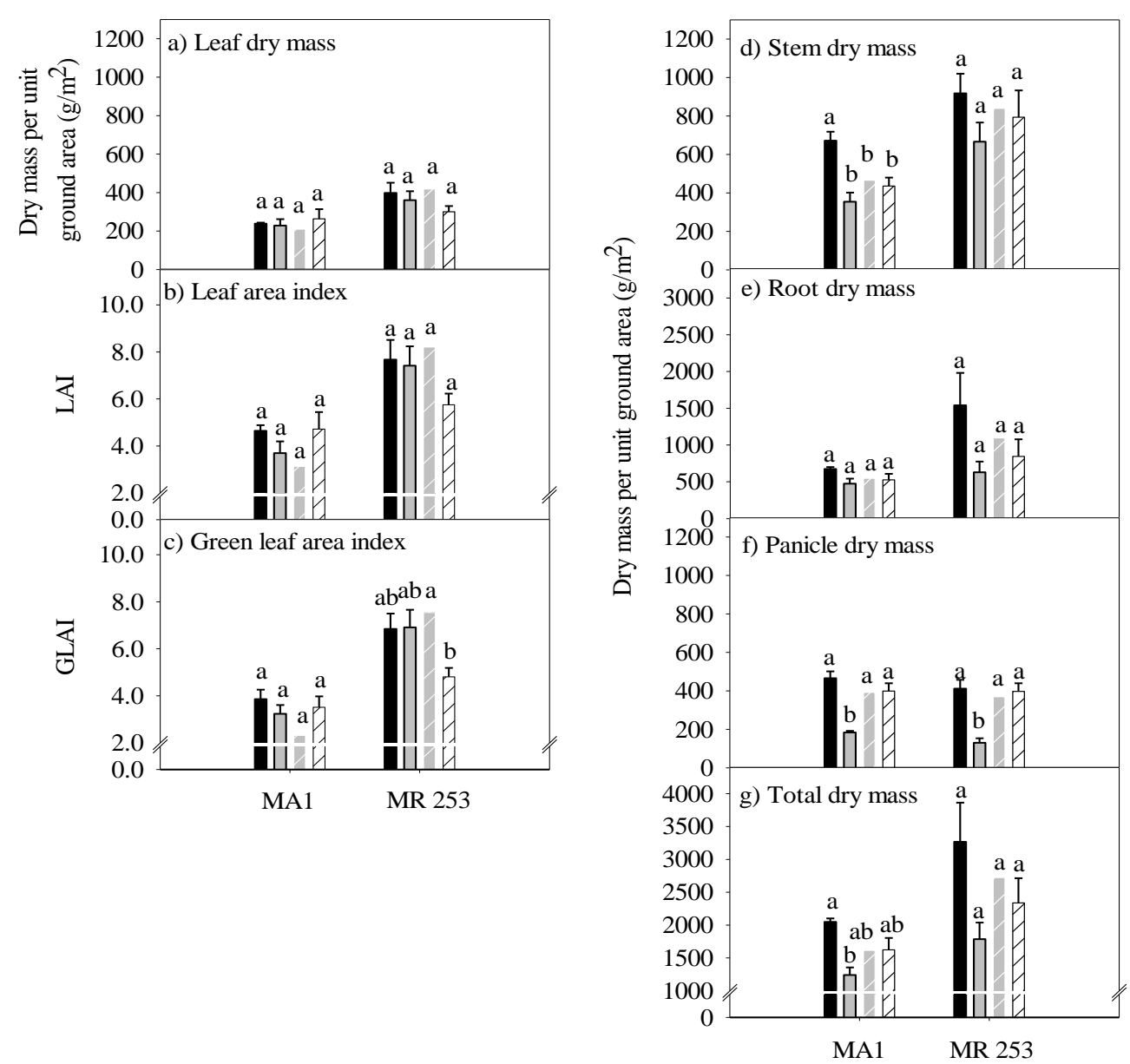

ש=control; water stress at $\square$ =panicle initiation, $\square=$ =flowering, $\square=$ =ripening

Fig 2. Leaf dry mass (a), leaf area index (b), green leaf area index (c), stem dry mass (d), root dry mass (e), panicle dry mass (f) and total dry mass (g) of MA1 and MR 253 varieties affected by water stress at selected growth stages. Values represent means with different letters represent significant difference between treatments at $p \leq 0.05$, and ns represents not significant difference between treatments $(n=6)$. 
Table 3. Phenological development of MA1 and MR 253 affected by water stress at selected growth stages.

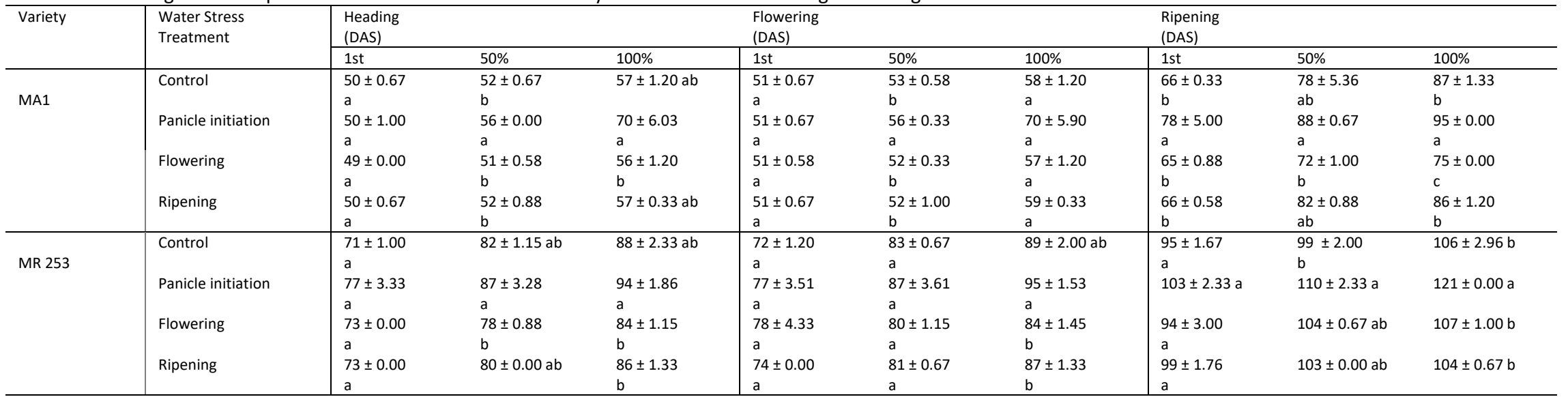

Values represent means with different letters represent significant difference between treatments at $p \leq 0.05(n=3)$.

Table 4: Correlation coefficients of various physiological parameters of MA1 and MR 253 during water stress period.

\begin{tabular}{llll|lll}
\hline & \multicolumn{3}{c}{ MA1 } & \multicolumn{3}{c}{ MR 253 } \\
\cline { 2 - 7 } Var./Par. & Leaf RWC & SMC & HI & Leaf RWC & SMC & HI \\
\hline Leaf RWC & - & - & $0.17 \mathrm{~ns}$ & - & - & $0.43^{*}$ \\
SMC & $0.93^{* * *}$ & - & $0.25 \mathrm{~ns}$ & $0.73^{* * *}$ & - & $0.58^{* *}$ \\
LDM & $0.01 \mathrm{~ns}$ & $0.06 \mathrm{~ns}$ & $0.18 \mathrm{~ns}$ & $0.05 \mathrm{~ns}$ & $0.28 \mathrm{~ns}$ & $-0.22 \mathrm{~ns}$ \\
LAI & $0.27 \mathrm{~ns}$ & $0.33 \mathrm{~ns}$ & $0.27 \mathrm{~ns}$ & $0.06 \mathrm{~ns}$ & $0.21 \mathrm{~ns}$ & $-0.27 \mathrm{~ns}$ \\
GLAI & $0.35 \mathrm{~ns}$ & $0.40 \mathrm{~ns}$ & $0.20 \mathrm{~ns}$ & $0.08 \mathrm{~ns}$ & $0.18 \mathrm{~ns}$ & $-0.34 \mathrm{~ns}$ \\
SDM & $0.64^{* * *}$ & $0.68^{* * *}$ & $0.52^{* *}$ & $0.32 \mathrm{~ns}$ & $0.25 \mathrm{~ns}$ & $-0.06 \mathrm{~ns}$ \\
RDM & $0.39 \mathrm{~ns}$ & $0.41^{*}$ & $0.45^{*}$ & $0.47^{*}$ & $0.40 \mathrm{~ns}$ & $-0.03 \mathrm{~ns}$ \\
PDM & $0.40 \mathrm{~ns}$ & $0.41^{*}$ & $0.79^{* * *}$ & $0.17 \mathrm{~ns}$ & $0.59^{* *}$ & $0.40 \mathrm{~ns}$ \\
TDM & $0.53^{* *}$ & $0.56^{* *}$ & $0.66^{* * *}$ & $0.43^{*}$ & $0.44^{*}$ & $-0.01 \mathrm{~ns}$ \\
\hline
\end{tabular}

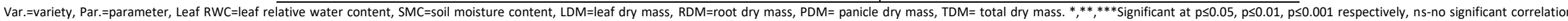


Table 5. Yield components of MA1 and MR 253 as affected by water stress at selected growth stages.

\begin{tabular}{|c|c|c|c|c|}
\hline \multirow{2}{*}{ Variety } & \multirow{2}{*}{ Treatment } & \multicolumn{2}{|c|}{$\%$ Grain } & \multirow{2}{*}{$\begin{array}{c}\text { Grain yield } \\
\left(\mathrm{kg} / \mathrm{m}^{2}\right)\end{array}$} \\
\hline & & Filled & Empty & \\
\hline \multirow{4}{*}{$\begin{array}{l}\text { MARDI } \\
\text { Aerob } 1\end{array}$} & Control & $69.5 \mathrm{~b}$ & $30.5 \mathrm{~b}$ & $0.54 \mathrm{a}$ \\
\hline & Water stress at the panicle initiation & $0.1 \mathrm{c}$ & 99.9 a & $0.00 \mathrm{~b}$ \\
\hline & Water stress at the flowering & $77.3 \mathrm{a}$ & $22.7 \mathrm{c}$ & $0.38 \mathrm{a}$ \\
\hline & Water stress at the ripening & $66.2 \mathrm{~b}$ & $33.8 \mathrm{~b}$ & $0.53 \mathrm{a}$ \\
\hline \multirow{4}{*}{ MR 253} & Control & $59.5 \mathrm{a}$ & $40.5 \mathrm{c}$ & $0.67 a$ \\
\hline & Water stress at the panicle initiation & $1.9 \mathrm{c}$ & $98.3 \mathrm{a}$ & $0.00 \mathrm{c}$ \\
\hline & Water stress at the flowering & $10.6 \mathrm{~b}$ & $88.8 \mathrm{~b}$ & $0.07 c$ \\
\hline & Water stress at the ripening & $63.5 \mathrm{a}$ & $38.5 \mathrm{c}$ & $0.46 \mathrm{~b}$ \\
\hline
\end{tabular}

Values represent means with different letters represent significant difference between treatments at $p \leq 0.05$, and ns indicates no significant difference ( $n=18$ ).

agreement with Boonjung and Fukai (1996), where water stress at either late vegetative stage or a period between panicle initiation to anthesis resulted in maturation delay. However, water stress at the post-anthesis including the grain filling stage would accelerate the maturation period.

Water stress at all stages (panicle initiation, flowering and ripening) did not significantly affect leaf and root dry mass production, and leaf area index for both varieties (Fig. 2). Nevertheless, water stress at all growth stages significantly reduced the SDM of MA1 but not MR 253 variety. The PDM was significantly reduced in both varieties only when water stress occurred at the panicle initiation stage. Total dry mass (TDM) in MR 253 was not affected by water stress given at any stage, but TDM was reduced in MA1 when water stress was imposed at the panicle initiation stage. The different response between MA1 and MR 253 varieties could be due to variability in stress recovery rates, dehydration tolerance and ability to extract soil water by these varieties (Lilley and Fukai, 1994). The MR 253 variety had higher leaf, stem, root and total dry mass, compared to MA1 in all treatments, which might be associated with longer growing cycle of MR 253. Genotypes with longer vegetative duration and late flowering stage generally produce greater biomass (Devine, 2009). Higher LDM, LAI, GLAI, SDM, RDM and TDM of MR 253 than MA1 variety could also be attributed to higher tillering capacity or tiller number in MR 253 than MAI. In general, genotypes with late heading period were found to produce greater tiller number and biomass than early heading genotypes (Kondhia et al., 2015). High biomass production had also been associated with high ability of root system to extract soil water to be supplied to the aboveground parts (Jaleel et al., 2009). The study indicated that TDM and RDM of MR253 were higher than MA1 variety. In addition, higher root length range was observed in MR253 (21. 7 to $26.2 \mathrm{~cm}$ ). This was relatively longer than those observed in MA1 $(18.9$ to $24.8 \mathrm{~cm})$, regardless of treatments. The higher root length density and total root dry mass in $30 \mathrm{~cm}$ soil depth contributed to a greater extraction of soil water in rainfed rice genotype DHL-79 (Wade et al., 2012). Longer root system was shown to take shorter time in extracting the same volume of soil water as shown in Namsagui19 and KDML105 rice genotypes lines, which had longer root system than IR20 and IR62266 genotypes (Kamoshita et al., 1997). Higher RDM instead of LDM per unit area in both varieties also indicated greater resource allocation to roots. Under nitrogen and water limiting conditions, resource allocation to root was generally greater than to leaves (Bonan, 2002). This study also demonstrated that both varieties produced higher root dry mass than other parts (leaf, stem and panicle dry mass) regardless of treatments. Limited water, nutrients, and root damage were among probable reasons that lead to a higher carbohydrates allocation to the root instead of aboveground parts (Harris, 1992).

The correlation studies (Table 4) between the leaf relative water content and soil moisture content were highly significant in both varieties. However, the degree of relatedness in MR $253\left(r=0.73^{* * *}\right)$ was relatively lower than MA1 $\left(0.93^{* * *}\right)$, indicating that MR 253 was seemingly more tolerant variety to water stress condition than MAI. The correlation studies also showed that the TDM for both varieties had significant positive correlation with leaf RWC and SMC. It was suggested that poor assimilate translocation and partitioning to the sink (grain) would be the main reason for poor grain filling or grain sterility in rice, rather than source limitation or limited biomass production (Puteh et al., 2014). Poor seed set or grain filling in rice had been associated with reduction in panicle sink size under water stress condition (Quinones et al., 2017). Water stress during meiosis in pollen mother cell was also reported potentially as impairment factor in sugar metabolism enzymes and starch synthesis in anthers, leading to inhibition in starch accumulation in pollen and pollen sterility of rice (Sheoran and Saini, 1996).

Both MA1 and MR 253 varieties exhibited high percentage of empty grain, and marked reduction in filled grain percentage and grain yield when water stress was imposed at the panicle initiation stage (Table 5). These results were in agreement with Boonjung and Fukai (1996), where drought stress during panicle development severely reduced the spikelet number per panicle, percent filled grain and overall grain yield. Different rice varieties would respond differently to water stress condition (Sokoto and Muhammad, 2014). For MA1, water stress at the flowering stage resulted in increased percentage of filled grain and reduction in percentage of empty grain. In contrast to MR 253, water stress at the flowering stage resulted in reduction of percentage of filled grain and grain yield but increased the percentage of empty grain, whereas water stress at the ripening stage resulted in the reduction of grain yield only. On the contrary, the grain yield of MR 253 was also reduced under water stress at the flowering and ripening treatments, which might be due to high spikelet sterility. Spikelet sterility had been associated with 
limited source strength or supply of resources required for grain development rather than sink capacity (Sheehy et al, 2001). Water stress is generally resulted in higher percentage of empty grain, reduced grain weight and harvest index $(\mathrm{HI})$ due to reduction of photosynthesis and assimilate translocation to the grain (Sokoto and Muhammad, 2014). Other factors that can contribute to grain filling diminution were reduction of starch synthesis enzymes and sucrose accumulation due to water stress condition (Farooq et al., 2009). Yield-related attributes may vary among varieties. Comparatively, MR 253 had higher grain yield and percentage of empty grain, but lower percentage of filled grain, compared to MA1 under control treatment. The yield of MR 253 was relatively higher $\left(0.67 \mathrm{~kg} / \mathrm{m}^{2}\right)$ compared to MA1 $\left(0.54 \mathrm{~kg} / \mathrm{m}^{2}\right)$ under the control treatment. However, the results differed with findings of Xiaoguang et al. (2002) and Zainudin et al. (2014), who found that yield of aerobic rice varieties were greater than the lowland rice, with heavier 1000-grain weight under control condition. It was reported that the lowland rice variety MR 253, having longer growing cycle compared to MA1, could perform well even under less fertile or marginal soil environments (Sunian et al., 2012). The yield of MR 253 was also reported higher than MR 219, when they both grown under marginal soil, with average yield of 5937 and 5346 $\mathrm{kg} / \mathrm{ha}$, respectively (Sariam et al., 2012).

\section{Materials and Methods}

\section{Plant materials}

Two local varieties; an aerobic rice variety MARDI Aerob 1 (MA1) and lowland rice variety MR 253 were used as planting materials. Seeds were sown in a row at $130 \mathrm{~kg} / \mathrm{ha}$ seed rate and $25 \mathrm{~cm}$ distance between rows and all agronomic practices were based on recommended production manual (Sariam et al., 2015).

\section{Experimental site}

The field plot measuring 18.5 by $10.5 \mathrm{~m}$ was carried out in the experimental farm at the Faculty of Plantation and Agrotechnology, Universiti Teknologi MARA (UiTM) Melaka Jasin campus from August 2015 to January 2016. The soil series of this experimental site is Gajah Mati with an average $\mathrm{pH}$ of 5.95. The percentage of soil Nitrogen $(\mathrm{N})$, Phosphate $\left(\mathrm{P}_{2} \mathrm{O}_{5}\right)$ and Potash $\left(\mathrm{K}_{2} \mathrm{O}\right)$ are $0.15 \%, 0.01 \%$ and $0.068 \%$, respectively. The means for minimum and maximum temperatures, relative humidity and rainfall recorded during the experimental study (August 2015 to January 2016) were $24.7{ }^{\circ} \mathrm{C}, 32.4{ }^{\circ} \mathrm{C}, 83.3 \%$ and $230.4 \mathrm{~mm}$, respectively.

\section{Experimental design and treatments}

The experiment was carried out in a randomized complete block design (RCBD) with four treatments and three replications (blocks). The four treatments were; (T1) - No water stress (control), and water stress imposition at selected growth stages, (T2) - panicle initiation, (T3) - flowering, and (T4) - ripening stages. Experimental details with respect to plot size and ways of managing water stress was described elsewhere (Nadzariah et al., 2018). The imposition of water stress treatments differed between varieties due to different maturation period. Water stress treatments were terminated when water deficit symptoms such as leaf rolling and wilting were detected. The actual crop age and period of water stress duration are shown in Table 1.

\section{Plant sampling for biomass and yield components}

For each subplot, two $20 \mathrm{~cm}$ length row strips were randomly selected and tagged from two different rows within the sampling area. All plants within two $20 \mathrm{~cm}$-strips were harvested for biomass production and yield components studies.

\section{Phenological development}

Phenological observation based on the first, 50 , and $100 \%$ appearance/emergence of the following three stages; heading, flowering, and maturity were recorded. The observation was made based on a total population in sampling area $(1 \mathrm{~m} \times 1 \mathrm{~m})$ per replicate excluding the guard rows.

\section{Biomass production}

Biomass data were collected only during the final harvest at maturation. This was carried out at different days, depending on maturity of MARDI Aerob 1 and MR 253 varieties under different water stress treatments (Table 2). The collected data were dry mass (g) of leaf, stem, panicle, root and total, and leaf area (leaf area index and green leaf area index). All data obtained per row strip $(20 \mathrm{~cm}$ length) were then later converted into unit ground area per meter square $\left(\mathrm{m}^{2}\right)$.

\section{Yield components}

Grain yield, percentage of filled and empty grain were analysed using final yield harvest (Table 2). The samples were collected from two $20 \mathrm{~cm}$ length row strips per replicate for all yield components analysis. These were similar row strips used for biomass production analysis. Grain yield was calculated based on formulae by Yoshida (1981). The filled and empty grain percentages were based on three panicles randomly selected from different tillers and plants taken from the same row strip. There was a total of six panicle samples per replicate, and eighteen panicle samples per treatment.

\section{Leaf relative water content (Leaf RWC)}

Leaf samples for leaf RWC were taken in the morning at around 8 to 9 a.m. The measurement was conducted three times; before the start of or at the beginning of water stress imposition (baseline), followed with the middle stress period and the final measurement at the end of water stress period just before re-watering. Three leaves were selected randomly from different tillers of different plants, making the total of six leaf samples per replicate, and eighteen leaf samples per treatment. The leaf RWC was measured based on method 
described by Turner (1981). The leaf samples were cut into 1 $\mathrm{cm}$ length small pieces. The leaf fresh mass (FM) was weighed before the leaf was placed in petri dish containing distilled water and left for full imbibition overnight at the room temperature to obtain turgid mass (TM). The leaf was later oven-dried at $70{ }^{\circ} \mathrm{C}$ for 48 hours for dry mass (DM) determination. The percentage of leaf RWC was calculated as:

Leaf RWC $(\%)=[(\mathrm{FM}-\mathrm{DM}) /(\mathrm{TM}-\mathrm{DM})] \times 100$

\section{Soil moisture content (SMC)}

Soil samples were collected in the morning at around 8 to 9 a.m, on the same day with the leaf sampling for leaf RWC. Soil samples at 0 to $20 \mathrm{~cm}$ depth were collected randomly at three sampling points within a replicate, making the total of 9 readings per treatment per measurement time. The SMC was determined using Gravimetric method (Black, 1965). Approximately $10 \mathrm{~g}$ of fresh soil sample was weighed and placed into a crucible. The sample was then oven-dried at $105^{\circ} \mathrm{C}$ for 24 hours or until the weight remained constant. The sample was left to cool before recording of the oven-dried weight. Percentage of soil moisture content was calculated as:

SMC $(\%)=$ (soil fresh weight - soil oven-dried weight $)$ /soil oven-dried weight $\times 100$

\section{Statistical analysis}

The data analysis was done using one way Analysis of Variance (ANOVA) by Statistical Analytical System (SAS) 9.3 software. For phenological development, biomass production and yield components, the mean comparison between treatments were analysed using Tukey's multiple range test, while correlations between leaf RWC, SMC and biomass production parameters were analysed using Pearson correlation. All the statistical tests were analysed at $5 \%$ of significant level.

\section{Conclusion}

Panicle initiation stage was the most sensitive period for both MA1 and MR 253 varieties as water stress at this stage resulted in delayed phenological development, reduced panicle dry mass, and severe yield reduction for both varieties. For general yield performance, it was concluded that MR 253 performed better than MA1 under normal aerobic condition but not under water stress condition, while MA1 was still able to maintain reasonable high yield even under water stress condition, except when water stress occurred at the critical stage such as panicle initiation stage.

\section{Acknowledgement}

We would like to thank the Faculty of Plantation and Agrotechnology UITM, Farmers' Organization Authority (LPP) Merlimau, MARDI Serdang, MARDI Seberang Perai and Melaka for their cooperation in providing the research plot, planting materials, experimental inputs and information for this study.

\section{References}

Acquaah G (2009) Principles of plant genetics and breeding. John Wiley \& Sons, UK.

Asch F, Dingkuhn M, Sow A, Audebert, A (2005) Droughtinduced changes in rooting patterns and assimilate partitioning between root and shoot in upland rice. Field Crop Res. 93(2-3): 223-236.

Black CA (1965) Methods of soil analysis: part I physical and mineralogical properties. American Society of Agronomy, Wisconsin, USA.

Bonan GB (2002) Ecological climatology concepts and applications, 1st edn. Cambridge University Press, New York.

Boonjung H, Fukai S (1996) Effects of soil water deficit at different growth stages on rice growth and yield under upland conditions. 2. Phenology, biomass production and yield. Field Crop Res. 48(1): 47-55.

Chauhan BS, Abugho SB (2013) Effect of water stress on the growth and development of Amaranthus spinosus, Leptochloa chinensis, and rice. American J Plant Sc. 4(05): 989.

Devine MD (2009) Enhancing crop productivity through increased abiotic-stress tolerance and biomass production. In: Eaglesham A, Hardy RWF (eds) Adapting agriculture to climate change. Proceedings of the twentyfirst annual conference of the National Agricultural Biotechnology Council, Saskatoon, Saskatchewan, 24-26 June 2009.

Farooq M, Wahid A, Kobayashi N (2009) Plant drought stress: effects, mechanisms and management. Agron Sustain Dev. 29(1): 185-212.

Fukai S, Kamoshita A (2005). Ecological, morphological, and physiological aspects of drought adaptation of rice in upland and rainfed lowland systems. In: Toriyama K, Heong KL, Hardy B (eds) Rice is life: scientific perspectives for the 21st century. Proceedings of the world rice research conference held in Tokyo and Tsukuba, Japan, 4-7 November 2004.

Haque MA, Lee TS, Gevao SMB (2006) Water distribution and water use assessment in rice cropping systems. Songklanakarin J Sci Technol. 28(4): 841-851.

Harris RW (1992) Root-shoot ratios. Paper presented at the annual conference of the international society of arboriculture in Philadelphia, August 1991.

Jaleel CA, Manivannan P, Wahid A, Farooq M, Al-Juburi HJ, Somasundaram R, Panneerselvam R (2009) Drought stress in plants: a review on morphological characteristics and pigments composition. Int J Agric Biol. 11(1): 100-105.

Kamoshita A, Wade L, Azhiri-Sigari T, Yamauchi, A (1997) Genotypic variation in drought recovery among rice seedlings. In: Abe J, Morita $S$ (eds) Root system management that leads to maximize rice yields. JSRR, Tokyo. pp. 32-33.

Kondhia A, Tabien RE, Ibrahim A (2015) Evaluation and selection of high biomass rice (Oryza sativa L.) for drought tolerance. American J Plant Sc. 6: 1962-1972.

Lal B, Priyanka G, Ekta J (2013) Different rice establishment methods for producing more rice per drop of water: a review. Int J Res BioSciences. 2(2): 1-12.

Lilley JM, Fukai S (1994) Effect of timing and severity of water deficit on four diverse rice cultivars III phenological 
development, crop growth and grain yield. Field Crop Res. 37(3): 225-234.

Lu JJ, Chang TT (1980) Rice in its temporal and spatial perspective. In: Luh BS (ed) Rice production and utilization. AVI Publishing Co., USA. pp. 1-74.

Mitchell J, Owusu M, Fukai S (2012) Root development of rice under flooded and aerobic conditions. In: Yunusa I (ed) Capturing opportunities and overcoming obstacles in Australian agronomy. Proceedings of 16th Australian agronomy conference, 14-18 October 2012.

Nadzariah KZ, Mohd Yusoff A, Sariam O, Nadzirah KZ (2018) Growth and physiological performance of aerobic and lowland rice as affected by water stress at selected growth stages. Rice Sci. 25(2): 82-93.

Puteh AB, Mondal MMA, Ismail MR, Latif MA (2014) Grain sterility in relation to dry mass production and distribution in rice (Oryza sativa L.). BioMed Res Int. 2014: 175-185.

Quinones C, Mattes N, Faronilo J, Jagadish K S (2017) Drought stress reduces grain yield by altering floral meristem development and sink size under dry-seeded rice cultivation. Crop Sci. 57(4):1-11.

Richards RA (2000) Selectable traits to increase crop photosynthesis and yield of grain crops. J Exp Bot. 51: 447458.

Sariam O, Azmi M, Chan CS, Badrulhadza A, Mohd Khusairy K, Mohd Fitri M, Allicia AJ, Rosnani H, Shamsul Amri S (2015) Manual teknologi penanaman padi aerob (Manual of aerobic rice cultivation technology). MARDI, Malaysia.

Sariam O, Zainuddin PMDH, Sunian E, Shahida H (2012) Yield performance of rice varieties MR 253 and MR 263 in different soil fertility zones. Buletin Teknologi MARDI, 1(2012): 41-48.

Shahzad MA, Jan SU, Afzal F, Khalid M, Gul A, Sharma I, Sofo A, Ahmad P (2016) Drought stress and morphophysiological responses in plants. In: Ahmad P (ed) Water stress and crop plants: a sustainable approach. John Wiley \& Sons, UK. pp. 452-467.

Shashidhar HE (2007) Aerobic rice: An efficient water management strategy for rice production. In: Aswathanarayana U (ed) Food and water security. Taylor \& Francis Group, UK. pp. 131-139.

Sheehy JE, Dionora MJA, Mitchell PL (2001) Spikelet numbers, sink size and potential yield in rice. Field Crop Res. 71(2): 7785.
Sheoran IS, Saini HS (1996) Drought-induced male sterility in rice: changes in carbohydrate levels and enzyme activities associated with the inhibition of starch accumulation in pollen. Sex Plant Reprod. 9(3): 161-169.

Sokoto MB, Muhammad A (2014) Response of rice varieties to water stress in Sokoto, Sudan Savannah, Nigeria. Journal of Biosciences and Medicines, 2: 68-74.

Steponkus PL, Ctler JM, O'Toole JC (1980) Adaptation to water stress in rice. In: Turner NC, Kramer PJ (eds) Adaptations of plants to water and high temperature stress. John Wiley \& Sons, Canada. pp. 401-418.

Sunian E, Azlan S, Zainudin PMDH, Saad A, Alias I, Othman O, Muhammad Naim Fadzli AR, Muhamad $H$, Asfaliza $R$, Mohamad Najib MY, Nurkhairani AB, Amirrudin M, Maisarah MS, Shahida H, Siti Norsuha M (2012) MR 253: Varieti padi baharu rintang terhadap penyakit karah dan sesuai ditanam di tanah bermasalah (MR 253: new rice varieties resistant to blast disease and suitable for planting on marginal soil). Buletin Teknologi MARDI. 1: 23-31.

Turner NC (1981) Techniques and experimental approaches for the measurement of the plant water status. Plant Soil, 58: 339-366.

Vadez V, Kholova J, Choudhary S, Zindy P, Terrier M, Krishnamurthy L, Kumar PR, Turner NC (2011) Responses to increased moisture stress and extremes: whole plant response to drought under climate change. Crop adaption to climate change, 1st edn. John Wiley and Sons, UK. pp. 186197.

Wade LJ, Siopongco J, Komoshita A, Samson BK, Acuna T (2012). Assessing root growth and water extraction for rainfed rice. In: Shashidhar HE, Henry A, Hardy B (eds) Methodologies for root drought studies in rice. IRRI, The Philippines. pp. 27-33.

Xiaoguang $Y$, Huaqi W,Zhimin W, Junfang Z, Bin C, Bouman BAM (2002) Yield of aerobic rice (Han Dao) under different water regimes in North China. In: Bouman BAM, Hengsdijk $\mathrm{H}$, Hardy B, Bindraban PS, Tuong TP, Ladha JK (eds) Water-wise rice production. IRRI, The Philippines. pp. 155-165.

Yoshida S (1981) Fundamentals of rice crop science. IRRI, The Philippines. pp.1-64.

Zainudin H, Sariam O, Chan CS, Azmi M, Saad A, Alias I, Marzukhi H (2014) Performance of selected aerobic rice varieties cultivated under local condition. J Trop Agric and Fd Sc. 42(2): 175-182. 